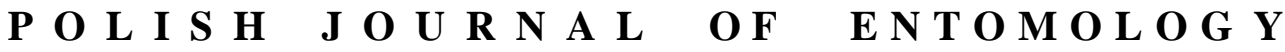

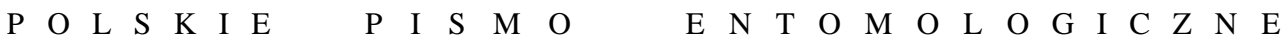

VOL. 86: 141-164

Lublin

30 June 2017

DOI: $10.1515 /$ pjen-2017-0010

\section{The Moravian Gate as route of migration of thermophilous bee species to Poland: fact or myth? A case study in the "Góra Gipsowa" steppe reserve and other habitats near Kietrz}

\author{
JÓZEF BANASZAK, LUCYNA TWERD, ANNA SOBIERAJ-BETLIŃSKA*, \\ BARBARA KILIŃSKA \\ Department of Ecology, Institute of Environmental Biology, \\ Kazimierz Wielki University, 12 Ossolińskich Av., 85-093 Bydgoszcz, Poland
}

\begin{abstract}
This study complements earlier research on wild bees (Apiformes) in the "Góra Gipsowa" steppe reserve and other habitats near the town of Kietrz (SW Poland), close to the Czech border. It also attempts to reassess the opinion of some researchers about the Moravian Gate as a migration route of southern species to Poland. 109 bee species were recorded at the study sites, including 10 red-listed ones; southern species accounted for $16.5 \%$ of this number. The hypothetical route of migration of thermophilous bees through the Moravian Gate to Poland was analysed and the species composition of southern species at either side of the Moravian Gate compared. The results of this study indicate that at present the Moravian Gate plays no part in the migration of southern bee species to Poland.
\end{abstract}

KEY WORDS: Hymenoptera, Apoidea, Apiformes, SW Poland, xerothermic habitats, "Góra Gipsowa" nature reserve, Moravian Gate.

\section{INTRODUCTION}

This study complements earlier research on the species composition of wild bees (Apiformes) in the "Góra Gipsowa" steppe reserve (BANASZAK et. al. 2013c, TwERD

\footnotetext{
*Corresponding author: anna.sobieraj@ukw.edu.pl
} 
\& BANASZAK 2013) and its vicinity in the Opole region of SW Poland. Using wild bees as an example, we also attempted to reassess earlier opinions about the Moravian Gate as a migration route of southern species to Poland.

The Moravian Gate is a natural pass, about $65 \mathrm{~km}$ long and $15 \mathrm{~km}$ wide (MAIER 2015), between the eastern Sudetens and the western Carpathians near the headwaters of the Rivers Oder and Vistula (PENN 2001). According to many botanists, southern xerothermic plant species migrated to the Poland through the Moravian Gate (SZAFER 1926, MedweCKa-Kornaś \& Kornaś 1977, PaWŁowsKa 1977, SendeK \& BabCZyŃSKaSENDEK 1990). One of the species that presumably migrated northwards through the Moravian Gate is Quercus pubescens WILLD., a species native to the Mediterranean region. In Poland, this species is present in only one locality, the nature reserve "Bielinek" (Pomeranian Lakeland), far to the north of the northern limit of its continuous range. Other plant species that have probably migrated northwards from southern Europe in the same way include Anthericum liliago L., Lithospermum purpurocaeruleum L., Dorycnium herbaceum VILL., D. germanicum (GREMLI) RIKLI and Orchis tridentata SCOP. (WODZICZKO et al. 1948). However, molecular analyses (CIEŚLAK 2015) have not confirmed the migration of xerothermic plant species from south to north through the Moravian Gate.

The presence of xerothermic vegetation indicates that animals with similar requirements can be expected there. For example, the European ground squirrel Spermophilus citellus (LINNAEUS, 1766) most probably migrated to Silesia through the Moravian Gate (SURDACKI 1965). Among invertebrates, the weevil Helianthemapion velatum (GERSTAECKER, 1854) (Coleoptera: Apionidae) is a particularly noteworthy migrant (MAZUR \& PAWŁOWSKI 1993, WANAT \& CELADYN 2015). Other examples of species that have arrived in our country via this depression between the Carpathians and the Sudetens are Aphis vitalbae FERRARI, 1872 (Hemiptera, Sternorrhyncha: Aphididae) (HAŁAJ \& OSIADACZ 2015), Cymatia rogenhoferi (FIEBER, 1864) (Hemiptera, Heteroptera: Corixidae) (KARG 1966), Pinthaeus sanguinipes (FABRICIUS, 1781) (Hemiptera, Heteroptera: Pentatomidae) (CHŁOND \& GoRCZYCA 2009) and probably also Eucharis adscendens (FABRICIUS, 1787) (Hymenoptera, Apocrita: Eucharitidae) (SZAFRAŃSKI 2011), Bittacus hageni BrAUER, 1860 (Mecoptera: Bittacidae) (PRZYBYŁOWICZ 2006) and Mantis religiosa religiosa (LINNAEUS, 1758) (Mantodea) (KRÓLIK 2010). BUSZKO (1990) describes two possible migration routes of xerothermophilous species of mining lepidopterans in Poland: from the west along the River Noteć to the Lower Vistula, and from the south through the Moravian Gate to the upper Vistula and Oder. Nevertheless, results of 40 years of observations on weevils (Coleoptera: Rhynchitidae, Apionidae, Nanophyidae and Curculionidae) (KUŚKA (2001) emphasize the minor part played by the Moravian Gate in the spread of xerothermophilous species to Poland, and show that the 
migration of species from the south was possible only after the initiation of agriculture. LIANA (1976), who attempted to assess the role of the Moravian Gate in the migration of xerothermophilous orthopterans to the Małopolska Upland, was of a similar opinion.

In relation to bees, a number of publications relating to southern Poland, i.e. Lower and Upper Silesia, the Małopolska Upland and the Kraków-Częstochowa Upland, have turned out to be very useful (DITTRICH 1903, ŁOZIŃSKI 1920, NOSKIEWICZ 1924, 1950, 1959, Macko \& NoskieWicZ 1954, 1959, Celary 1988, 1995, 1999, 2000, Celary \& WIŚNIOWSKI 2001, 2003, 2007, 2011), as well as others concerning the Czech Republic (P̌̌IDAL \& VESElÝ 2011, STRAKA et al. 2007, PřIDAl 2014) or Slovakia (LuKÁŠ 1983, 1987, STRAKA et al. 2007, PŘIDAL 2014). We have attempted to assess the possibility of bee migration to Poland through the Moravian Gate on the basis of these papers.

\section{MATERIAL AND METHODS}

\section{Study area}

With respect to the physical geographical division of Poland (KONDRACKI 2002), the study area lies at the exit of the Moravian Gate (Moravia, Czech Republic), within the Silesian Lowland macroregion (Nizina Śląska) and the Głubczyce Plateau mesoregion (Płaskowyż Głubczycki). According to the latest geobotanical regionalization (MATUSZKIEWICZ 2008), the area is situated in the Brandenburg-Wielkopolska Division, Lower Silesian Land, Głubczyce Plateau District and Głubczyce-Racibórz Subdistrict. Climatically, it is in the Southern Lower Silesia region (XXV). The area has few days with ground frost, very cold weather and overcast sky, and likewise few days with ground frost, very cold weather and precipitation (Woś 1993).

We specified the location of the six study sites in the eastern Sudetens (RAFALSKI 1960) on the UTM grid $(10 \mathrm{~km} \times 10 \mathrm{~km})$ and of the zoogeographic region using the http://gis.biomap.pl application. They are briefly described below and their location is shown on a map (Fig. 1).

1. "Góra Gipsowa" steppe reserve (UTM: YR14). This nature reserve is situated close to the town of Kietrz, on the southern slopes of the Góra Gipsowa (altitude $285 \mathrm{~m}$ ), which are composed of clayey gravels overlying Miocene gypsum deposits (KUŚKA 2001). This habitat is an island among intensive farmland. The specific geological structure and former 


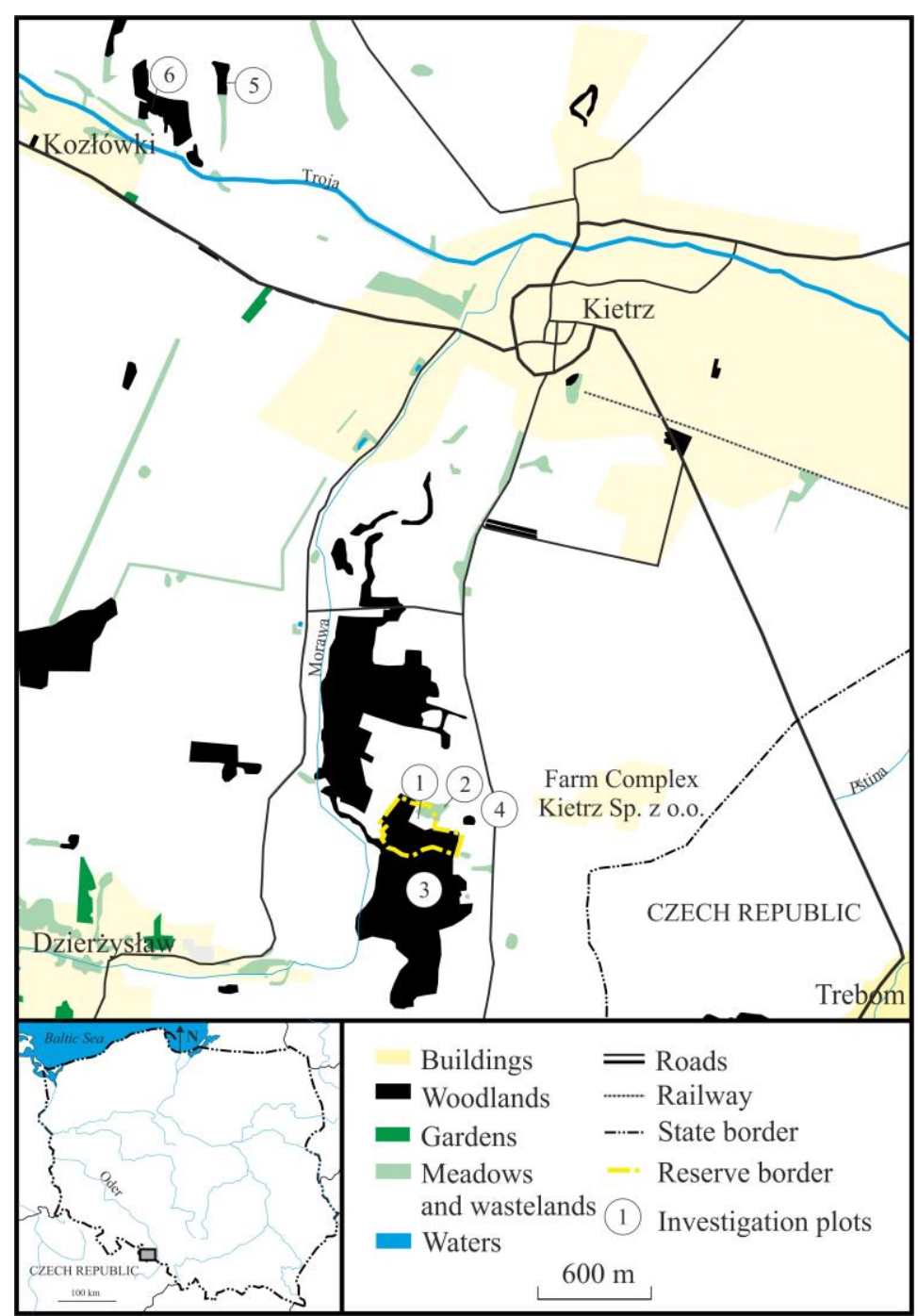

Fig. 1. Location of study sites: 1 = "Góra Gipsowa" steppe reserve; 2 = wooded patch; 3 = disused gypsum mine "Dzierżysław"; 4 = roadside; 5 = gully between fields; $6=$ forest glade.

use of this site as pastureland enabled xerothermic grasslands of the class FestucoBrometea to develop. The most stable plant community there is flowery steppe ThalictroSalvietum pratensis (SENDEK \& BABCZYŃSKA-SENDEK 1990), in which many plant species typical of steppe and shrub communities are found, e.g. Achillea setacea WALDST. \& KIT., Anthericum ramosum L., Bupleurum falcatum L., Campanula bononiensis L., Cirsium 
pannonicum (L.F.) LINK, Dactylorhiza sambucina (L.) Soó, Elymus hispidus (OPIZ) Melderis, Festuca valesiaca SCHLEICH. ex GAUdiN, Inula hirta L., Ornithogalum collinum Guss., Potentilla alba L., Prunella grandiflora (L.) SCHOLLER., Tanacetum corymbosumm (L.) SCH. BIP., Thesium linophyllon L. and Verbascum phoeniceum L. The reserve was enlarged in 2016, so now it covers an area of 8.65 ha (ORDINANCE... 2016).

2. Wooded patch (UTM: YR14) bordering the northern edge of the "Góra Gipsowa" reserve. In spring, herbaceous bee forage plants are represented there by Chelidonium majus L., Lamium album L. and L. purpureum L.

3. The "Dzierżyslaw" gypsum mine, at the foot of the Góra Gipsowa (UTM: YR14). This disused mine is situated several kilometres south of Kietrz, very close to the Czech border. The site is largely overgrown by trees and shrubs. The main bee forage plant in spring is Chelidonium majus.

4. Roadside, along the road from Kietrz to the "Góra Gipsowa" reserve (UTM: YR14). Field research was conducted in a plot about $200 \mathrm{~m}$ long, where bee forage plants were represented in spring primarily by Alliaria petiolata (M. BIEB.) CAVARA \& GRANDE, Chelidonium majus, Lamium album and Taraxacum officinale F.H. WIGG.

5. Gully between fields near Kietrz (UTM: YR15). The gully is about $575 \mathrm{~m}$ long with slopes about $3.5 \mathrm{~m}$ in height. It runs nearly perpendicular to the valley of the submontane River Troja, close to the farmsteads in the village of Kozłówki. The substrate of the gully slopes shows it to be the result of erosion of loess soils and to some extent of older geological structures. The slopes are partly covered by trees - Acer pseudoplatanus L., Betula pendula RоTH, Crataegus monogyna JACQ., Salix sp. and Quercus sp. - and shrubs - Sarothamnus scoparius (L.) W.D.J. Koch, Prunus sp., Rosa canina L. and Sambucus nigra $\mathrm{L}$. The ground layer of vegetation is dominated by grasses and other herbaceous plants, e.g. Alliaria petiolata, Anthriscus sp., Euphorbia sp., Galium sp. and Viola sp. In the depression at the northern end of the gully, the major bee forage plants are Chelidonium majus and Lamium purpureum. Ranunculus illyricus L., a species typical of xerothermic grasslands and currently critically endangered in Poland, used to be recorded at this site (WODZICZKO et al. 1948, KuŚKA 2001).

6. Forest glade near Kozłówki (UTM: YR15) with a patch of Lamium purpureum flowering abundantly in spring. It is surrounded by deciduous forest. The tree layer is dominated mainly by Fraxinus excelsior L. (about 60-80 years old).

Earlier research carried out in the "Góra Gipsowa" reserve and near Kietrz

Only four groups of insects have been relatively well studied in the "Góra Gipsowa" steppe reserve: Coleoptera (SZYMCZAKOWSKI 1965, KUŚKA 1977, 1981, 2001, 2006, 2007, MelKe \& GrZYwocz 2002, GreŃ et al. 2015), Heteroptera (Hebda 2002, 2004), Orthoptera (LIANA 1976) and recently wild bees Apiformes (BANASZAK et. al. 2013c, 
TWERD \& BANASZAK 2013). TWERD \& BANASZAK (2013) perceived a probable threat to the "Góra Gipsowa" reserve: because it lies among intensively farmed arable fields, it is exposed to the agrochemicals, not always properly applied, that the owners of that land spray their crops with. The dramatic decline in the number of wild bee species and individuals in 2010 compared with 2008 was most probably due to the inappropriate use of such agrochemicals.

Among the insects of the gully between fields near Kietrz, only the coleopteran fauna has so far been explored (KUŚKA 2007). Additionally, during research on the wild bee fauna of the gully, a single specimen of an interesting heteropteran, Tritomegas sexmaculatus (RAMBUR, 1839), was found (SOBIERAJ-BETLIŃSKA in press). Until recently, this had been regarded as a typical xerothermophilous species, but it is being come across more and more frequently in urban areas (mainly ruderal habitats and gardens) (LIS et al. 2012).

\section{Methods}

Earlier research in the "Góra Gipsowa" steppe reserve was carried out in the summer of 2008 (11-13 July) and 2010 (13-15 July). Wild bees were caught with an entomological net by searching on flowers and at the bees' favourite nesting sites. In 2015, supplementary field research was done in spring using the same methods at six sites: the "Góra Gipsowa" nature reserve ( 5 and 7 May), the wooded patch north of the reserve ( 5 and 7 May), the roadside along the road from Kietrz to the "Góra Gipsowa" reserve (5 and 7 May), the gully between fields near Kietrz ( 8 May), the forest glade near Kozłówki (6 and 8 May) and the disused "Dzierżysław" gypsum mine (7 May). The samples were collected on dry, sunny days, with very little or no wind, between 10:00 and 17:00 hrs. Quantitative methods were not applied. The Nature Conservation Officer and Regional Director of Environmental Conservation in Opole granted the necessary permission for collecting insects in the reserve during this study. The specimens collected were preserved, labelled and identified. They are deposited in the collection of the Department of Ecology, Institute of Environmental Biology, Kazimierz Wielki University, Bydgoszcz.

The dominance of species is expressed as the percentages of a given species in the bee community. Five dominance classes are distinguished to describe various levels of the dominance index (D): eudominants $\left(\mathrm{D}_{5}\right)$, i.e. species accounting for $>10.0 \%$ of the total catch; dominants $\left(\mathrm{D}_{4}\right)$ 5.1-10.0\%; subdominants $\left(\mathrm{D}_{3}\right) 2.1-5.0 \%$; recedents $\left(\mathrm{D}_{2}\right) 1.1-2.0 \%$; and subrecedents $\left(D_{1}\right)<1.1 \%$ (KASPRZAK \& NIEDBAŁA 1981).

The scientific nomenclature of the bee species is taken from OsYTSHNJUK (1977), DATHE (1980), BANASZAK (2004), MichENER (2007) and DubitZKY et al. (2010), while the systematic classification of families follows MICHENER (2007). Within families, the lower taxa (genera and species) are listed alphabetically. The categories of threat to bee species 
are adopted after BANASZAK (2004). The legal status is based on the Regulation of the Minister of Environmental Conservation of 16 December 2016 relating to the conservation of animal species.

The zoogeographical status of the bees was determined on the basis of monographs or publications relating to particular bee families (CELARY 1990, 1995, DYLEWSKA 2000, BanaszaK et al. 2001, PesenKo et al. 2000, 2002, PAwlikowski \& Celary 2003), and also on assessments of the first author.

The nomenclature of plant species is according to MIREK et al. (2002).

\section{RESULTS}

Species diversity and dominance structure of wild bees (Apiformes) in the "Góra Gipsowa" reserve and other habitats near Kietrz

During field research in 2008, 2010, and 2015, a total of 1622 wild bee specimens were collected, representing 109 species (Table 1). Accounting for 23\% of native Apiformes (BANASZAK 2004, BANASZAK et al. 2013a, WENDZONKA 2014, MOTYKA \& BYSTROWSKI 2016, МотYKA et al. 2016, PAWLIKOWSKI et al. 2016), they belong to 6 families and 32 genera.

The percentages of bee families in the total number of bee species in the study area were as follows: Colletidae (11.9\%), Andrenidae (19.3\%), Halictidae (18.3\%), Melittidae (2.8\%), Megachilidae (20.2\%) and Apidae (27.5\%).

The eudominants in the wild bee communities were Anthophora plumipes (13.9\%) and Andrena flavipes (11.7\%), while Bombus terrestris (7.5\%) and Nomada succincta (5.3\%) were dominants. The other taxa, classified as subdominants, recedents and subrecedents, together made up $61.7 \%$. The percentage contributions of individual species to the total catch (excluding Apis mellifera) varied from 0.1 to $13.9 \%$.

With regard to qualitative structure, the cleptoparasitic bee Nomada succincta and its host Andrena nigroaenea were dominant in the gully between fields. The partly bare, steep sides of the gully provide favourable nesting conditions for many bees. In contrast, the roadside and wooded patch in Kietrz and the forest glade near Kozłówki proved to be excellent habitats for the spring species Anthophora plumipes, which was abundant on flowers of Lamium album and L. purpureum. This bee species was represented by two subspecies - A. plumipes squalens Dours, 1869 (light-coloured form) and A. plumipes nigra (FRIESE, 1896) (black form). 


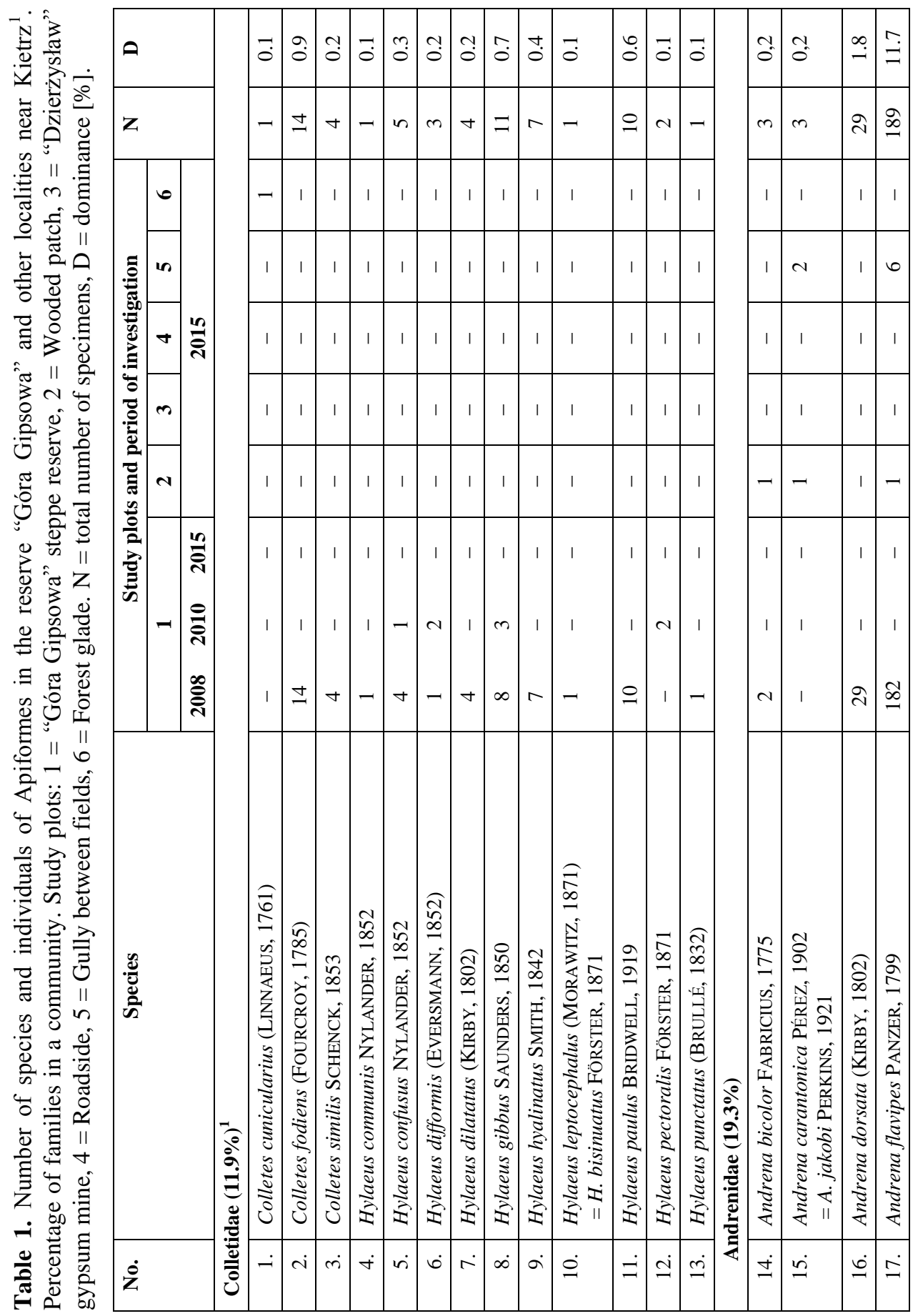




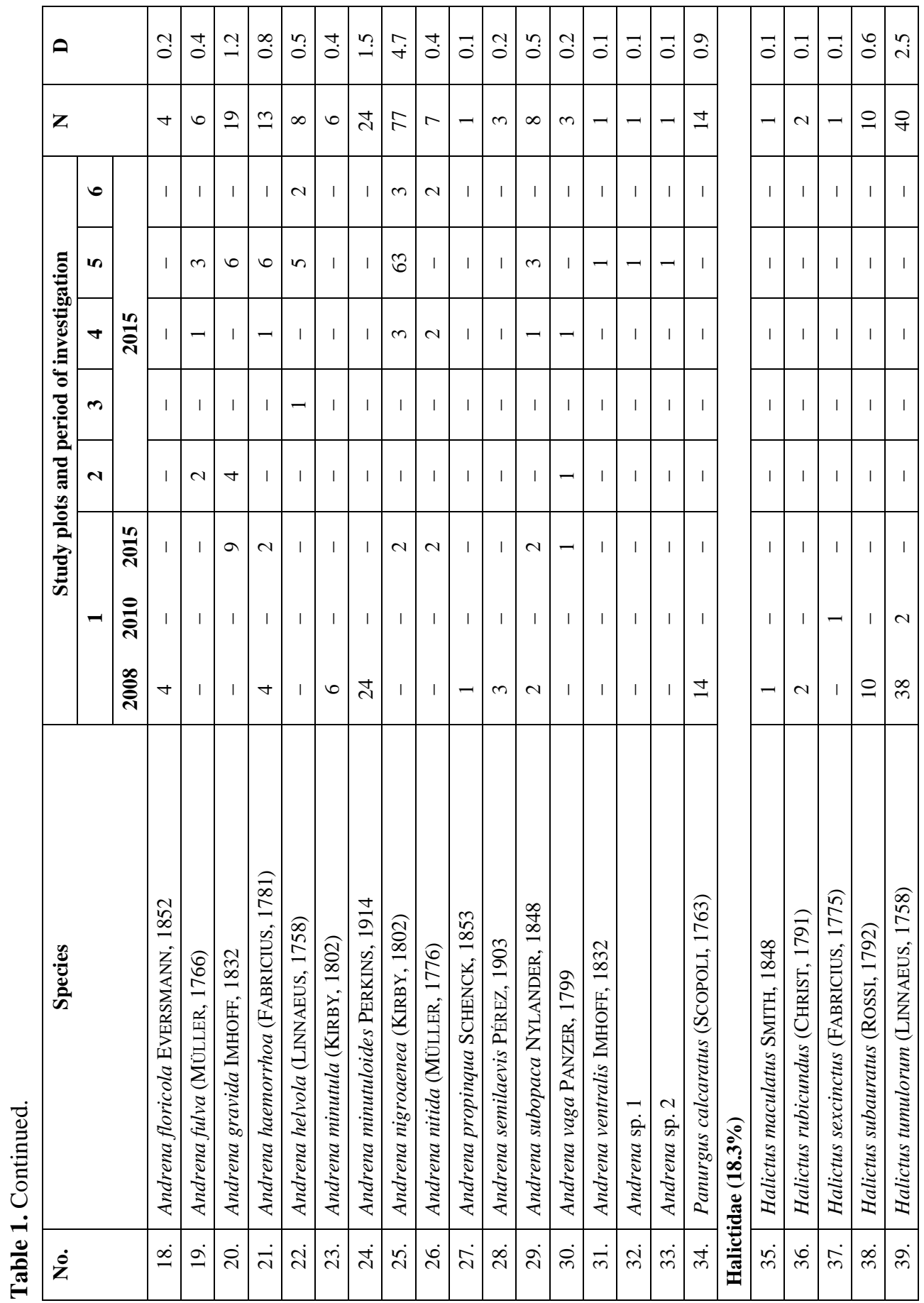




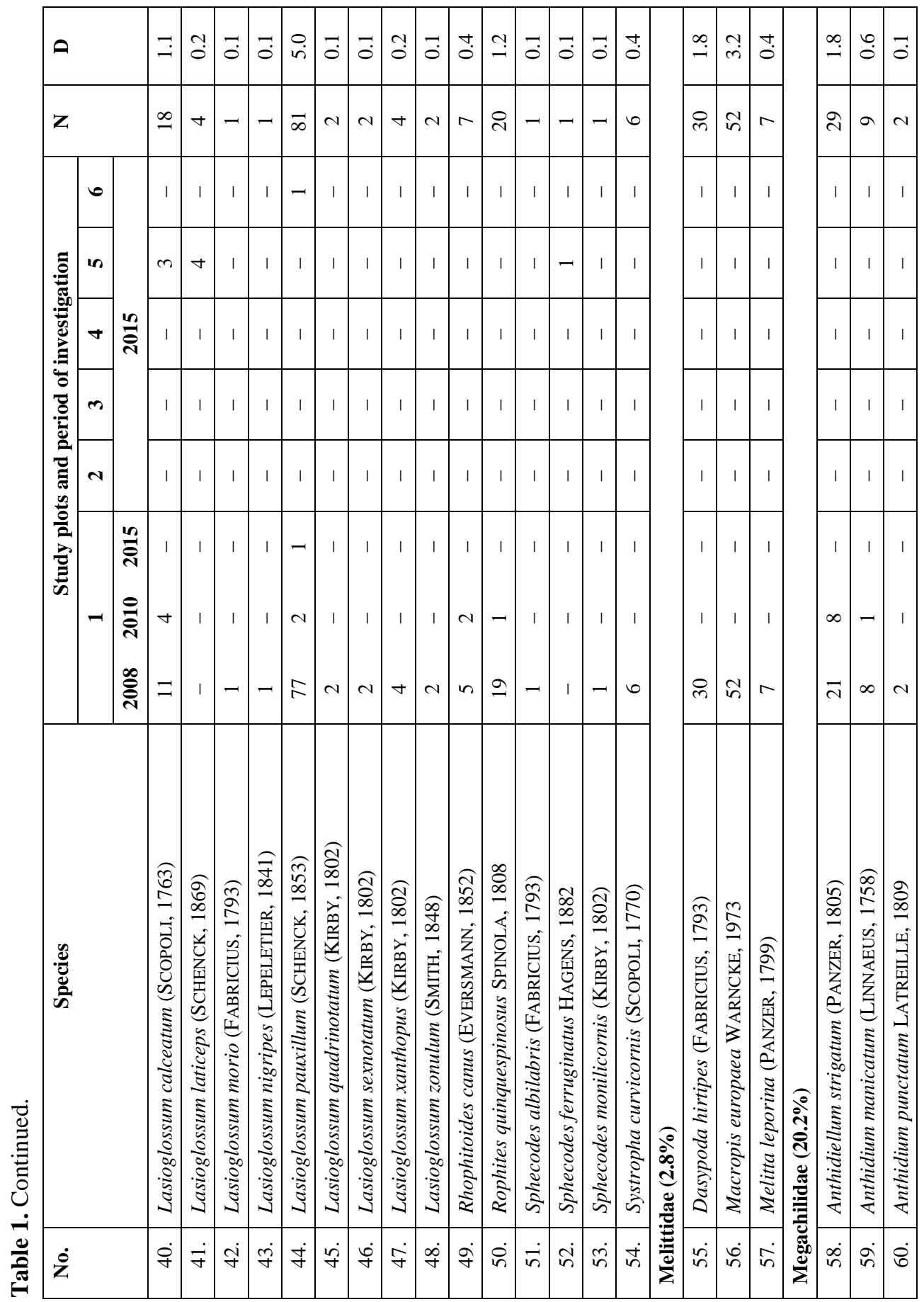




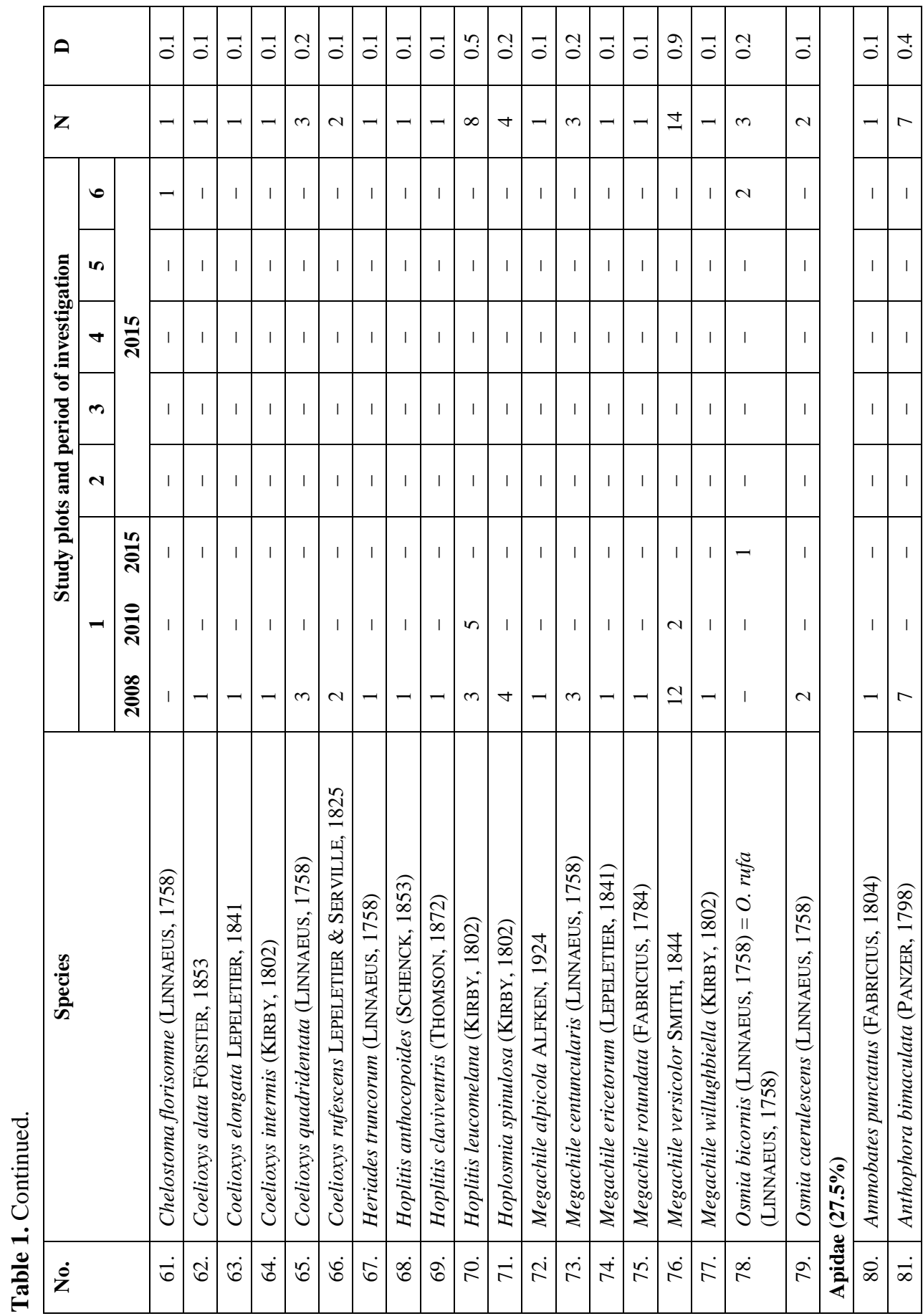




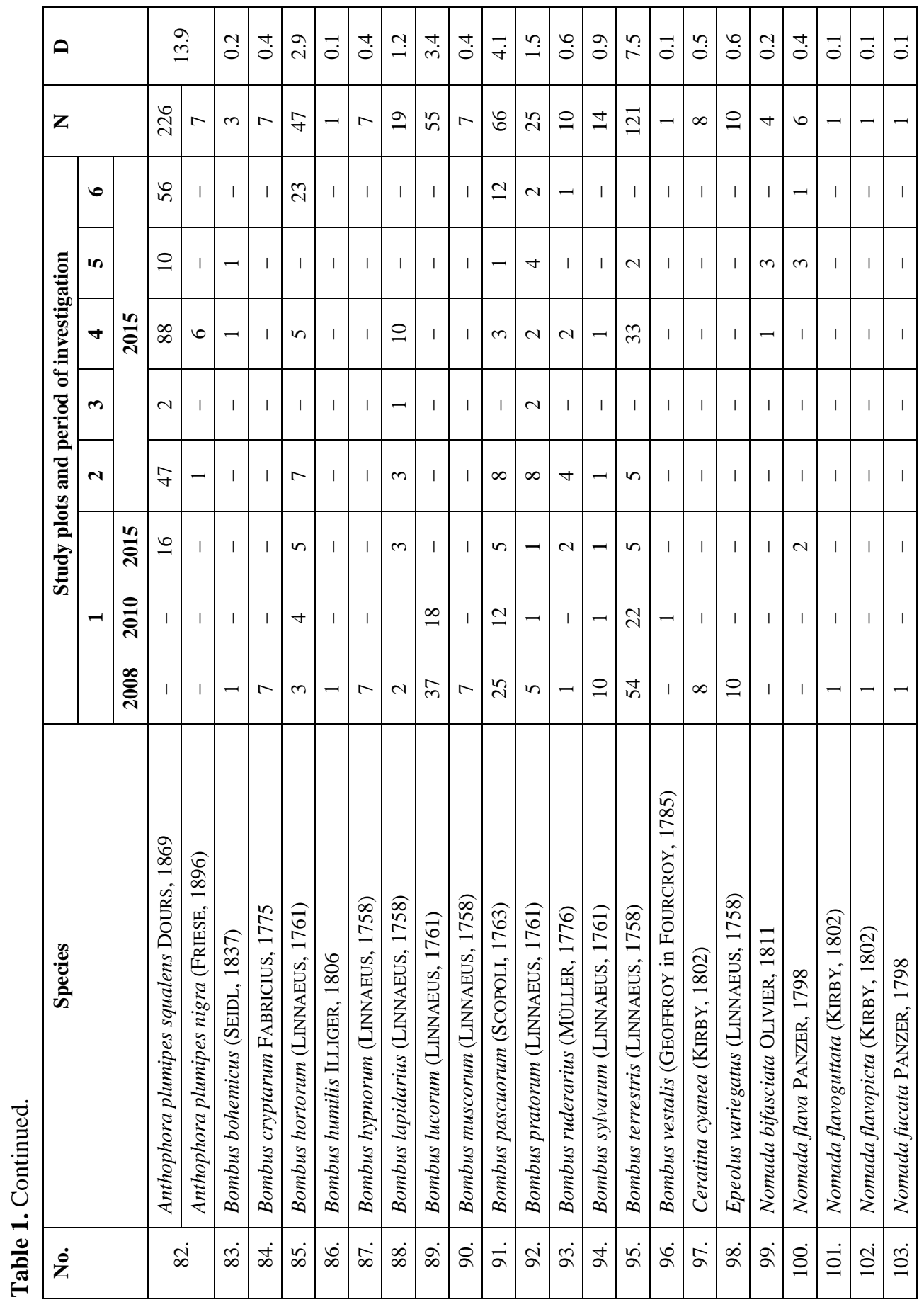




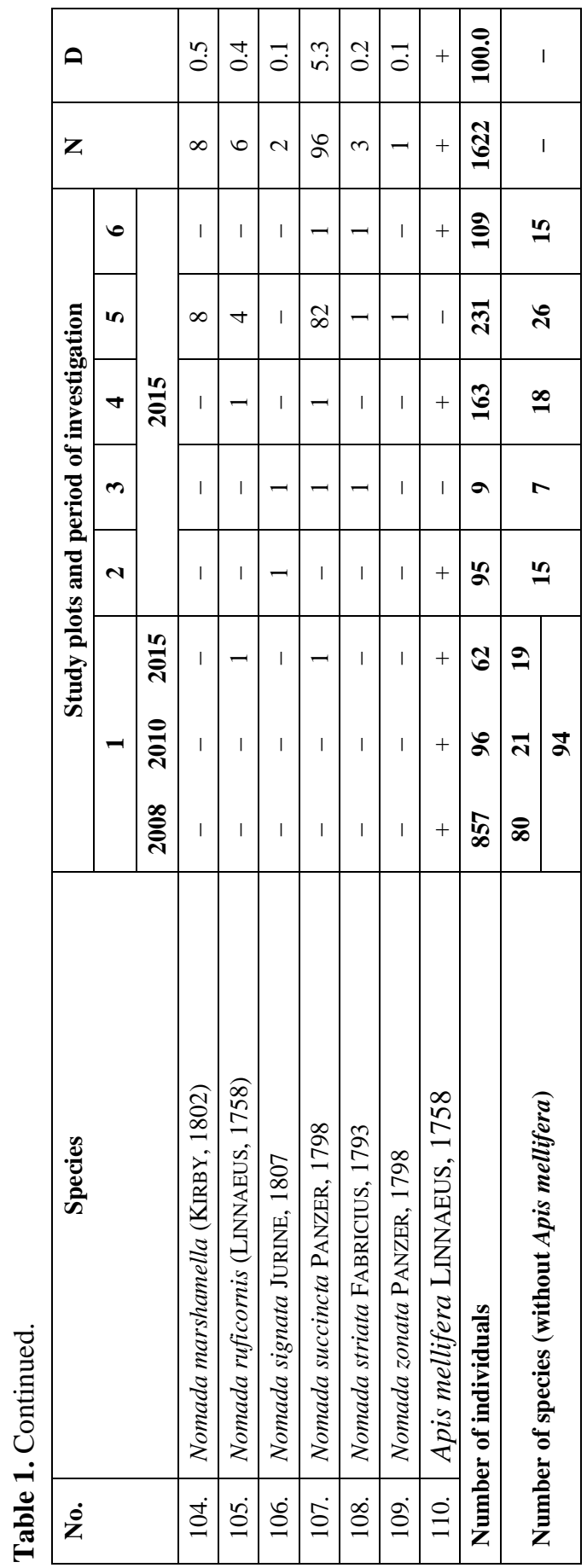


Ten of the 109 bee species recorded in the "Góra Gipsowa" reserve and other habitats near Kietrz are threatened (BANASZAK 2004); another twelve are partly protected by law in Poland (Regulation 2016). Andrena semilaevis and Hylaeus punctatus are vulnerable species (VU), while eight species - Ammobates punctatus, Coelioxys alata, Lasioglossum nigripes, Hylaeus leptocephalus, H. paulus, H. pectoralis, Nomada bifasciata and Systropha curvicornis - are classified as data deficient (DD) (BANASZAK 2004). In the study area, we recorded several species that are rare or very rare in Poland; they are briefly discussed below.

For a long time Hylaeus paulus was misidentified as $H$. gracilicornis. The former represents the Euro-Siberian element and has been reported from Austria, Germany, Poland, Switzerland, Mongolia, Siberia, the Russian Far East and Japan (CELARY 1999). In Poland it has been recorded in several localities: Rogaczewo near Kościanin Wielkopolska Province (BANASZAK 2000); Bolesław and Trzebniów in the Kraków-Częstochowa Upland (Celary 1999); Osicze and Miotełka in the Ojców National Park (Kraków-Częstochowa Upland) (CELARY \& WIŚNIOWSKI 2001); Bydgoszcz (leg. J. BANASZAK 2002), the vicinity of Szubin-Folusz (BANASZAK 2004) in the Wielkopolska-Kujawy Lowland; and Wejsuny on Lake Warnołty in Mazuria (BANASZAK 2010).

Ammobates punctatus is a very rare cleptoparasitic bee with a range in North Africa (Algeria) and in southern and central Europe. Females of this species lay their eggs in nests of Anthophora bimaculata (CELARY 1990). It has been recorded in various parts of Poland.

Systropha curvicornis, classified as a Western Palaearctic species (PESENKO et al. 2000), has been recorded in several localities in Poland in the last 24 years (KowALCZYK 1997, KowALCZYK et al. 2009ab, WiśNIOWSKI \& PIOTROWSKI 2013).

\section{Comparison of lists of southern species on either side of the Moravian Gate}

Southern species accounted for $16.5 \%$ (18 species) of the total number of species collected in the "Góra Gipsowa" reserve and the other habitats near Kietrz. This group includes Hylaeus difformis, H. leptocephalus, H. paulus, H. punctatus, Andrena flavipes, A. floricola, A. propinqua, Rhophitoides canus, Rophites quinquespinosus, Halictus sexcinctus, Lasioglossum nigripes, L. pauxillum, L. quadrinotatum, Sphecodes ferruginatus, Anthidiellum strigatum, Megachile rotundata, Nomada bifasciata and N. zonata.

Among the southern species found in the "Góra Gipsowa" reserve and the other habitats near Kietrz, Hylaeus punctatus could have used the Moravian Gate as a migration route to Poland. H. punctatus is a sub-Ponto-Mediterranean species that has reached Central Europe. Present in all parts of Poland, it has been observed primarily at sunny sites. It may also have migrated to Poland from the west. 
Lasioglossum nigripes is a Ponto-Mediterranean species. Infrequent in Poland, it has been reported from Wrocław (DITTRICH 1903), Sandomierz and Kazimierz Dolny (DYlewska \& Noskiewicz 1963), Góry Pieprzowe (NoskiewiCZ 1959, DYLEWSKA \& NosKIEWICZ 1963) and the "Zbocza Płutowskie" reserve (BANASZAK 1980). The species used to be common in the Podolia region (KunTZE \& NOSKIEWICZ 1938), so it will have migrated to Poland from there, but the localities in Wrocław and the "Góra Gipsowa" reserve support the hypothesis about the independent expansion of this species from Thuringia and Saxony. As this species lives in Bohemia, Moravia and Slovakia (STRAKA et al. 2007), it could also have migrated to Poland from the south through the Moravian Gate.

Sphecodes cristatus has not been recorded in the "Góra Gipsowa" reserve or in the other habitats near Kietrz, but its migration to Poland from the south through the Moravian Gate is probable. The range of $S$. cristatus lies in the southern temperate zone of the Western Palaearctic. A very rare species, it is known in most countries from just a few records (Bogusch \& STRAKA 2012). In Poland it has so far been recorded in the Mazovian Lowland (Dziekanów Polski, Łowicz), the Małopolska Upland ("Góry Pieprzowe"), Lower Silesia (Wrocław) (PESENKo et al. 2002) and the Kraków-Częstochowa Upland (Klucze, Olsztyn) (CELARY 2000). It has also been reported from Moravia and Slovakia (STRAKA et al. 2007) and recently even from Bohemia (STRAKA et al. 2015).

No bee species has been recorded in Lower Silesia in recent times which could provide incontrovertible evidence that southern bee species currently use the Moravian Gate as a migration route.

Table 2. Numbers and percentage of southern species in bee communities (Apiformes) of selected xerothermic habitats. 1 = LUKÁŠ 1987 ("Trenčianska Skalka", W Slovakia); 2 = LUKÁŠ 1983 ("Turecko" reserve, W Slovakia); 3 = PŘIDAL \& VESELÝ 2011 ("Mohelno Serpentine Steppe" national nature reserve, Czech Republic: SW Moravia); $4=$ this study.

\begin{tabular}{|l|c|c|c|c|}
\hline \multirow{2}{*}{\multicolumn{1}{|c|}{ Index }} & \multicolumn{4}{c|}{ Location } \\
\cline { 2 - 5 } & $\mathbf{1}$ & $\mathbf{2}$ & $\mathbf{3}$ & $\mathbf{4}$ \\
\hline Total number of species & 213 & 146 & 175 & 109 \\
\hline Number of southern species & 79 & 36 & 34 & 18 \\
\hline Percentage of southern species & 37.1 & 24.7 & 19.4 & 16.5 \\
\hline
\end{tabular}

A comparison of the percentages of southern species to the bee communities (Apiformes) in the "Góra Gipsowa" reserve and the nearby habitats with patches of xerothermic vegetation in the Czech Republic and Slovakia shows that they were conspicuously smaller in our study (Table 2). The species diversity of thermophilous bees 
was the highest in five selected biotopes in the "Trenčianska Skalka" conurbation around the city of Trenčin (W Slovakia) (79 species, LUKÁš 1987) and in the "Turecko" nature reserve (about 19 km SW of Trenčin) (36 species, LUKÁŠ 1983). 34 thermophilous species were found in the "Mohelno Serpentine Steppe" national nature reserve (Czech Republic: SW Moravia) (P̌̌IDAL \& VeSELÝ 2011).

\section{DISCUSSION}

This study complements our earlier research on wild bees in the xerothermic vegetation of the "Góra Gipsowa" reserve and other habitats near Kietrz. Some of our earlier results have already been published (BANASZAK et. al. 2013c, TWERD \& BANASZAK 2013). The aim of this paper was to assess the role of the Moravian Gate as a migration route of southern species to Poland. 109 wild bee species of 6 families were collected in the study area, accounting for about $23 \%$ of the total number of bee species in Poland. This is a relatively large number, considering the small size of the study sites.

Compared with the bee fauna of Poland as a whole (BANASZAK 2004, BANASZAK et al. 2013a, WendZONKA 2014, MоTYKA \& BYSTROWSKi 2016, МотYKA et al. 2016, PAWLIKOWSKI et al. 2016), the percentages of species from 4 bee families (Apidae, Colletidae, Megachilidae, Melittidae) were higher in this study. The Megachilidae are a very specialized group, and the high number of species from this family indicates that the nature reserve and its vicinity, despite the strong human impact they are subjected to, have preserved their natural value.

The "Góra Gipsowa" reserve and the other habitats near Kietrz are situated very close to the southern border of Poland, about $50 \mathrm{~km}$ from Hranice in the Czech Republic, in the narrowest part of the Moravian Gate, which appears to allow insects to use this migration route. There are limestone outcrops in Hranice and at Štramberk, several kilometres north of the town (KUŚKA 2001, 2006). The geographical location of study area offers an opportunity for the dispersal of thermophilous bee species from south to north, i.e. to Poland. However, in view of the lack of earlier data on the bee fauna of the "Góra Gipsowa" reserve and the other habitats near Kietrz, it is difficult to assess the scale of changes in the bee communities of the study area. One can only assume that such changes are basically associated with habitat transformations (MAZUR \& KUBISZ 2000, BANASZAK et al. 2010). The succession of plants in thermophilous vegetation reserves has always led top conspicuous changes in the species composition of wild bees (BANASZAK et al. 1998, 2003, CIERZNIAK et al. 2005). The successive degradation of the "Góra Gipsowa" reserve has certainly wrought changes in the composition of its insect fauna. We would expect a smaller number of species of highly specialized bees, with a narrow ecological tolerance, 
and of species that are incapable of long migrations (BANASZAK et al. 2013c). Following research on coleopterans, KUŚKA $(2006,2007)$ stated that 8 taxa had probably disappeared, confirming the substantial impoverishment of the habitat.

The species diversity of wild bees in the "Góra Gipsowa" reserve (94 species in an area of 1.72 ha) can be compared with those of habitat islands surrounded by meadows: the proposed "Folusz" nature reserve near Szubin ( 88 species on about 3 ha) (BANASZAK et al. 2004), the "Ostrów Małe Rudy" near Bydgoszcz (107 species in an area of about 6 ha) (BANASZAK et al. 2013b), and arable fields near Poznań and Turew (14-51 species in plots covering 0.23 to 0.5 ha) (BANASZAK \& CIERZNIAK 2002). It is evident that island size increases bee species diversity to a small extent. Habitat islands in the agricultural landscape near Turew and Poznań have far fewer species than islands in semi-natural habitats. In spite of its small size and location very close to intensively farmed fields, the "Góra Gipsowa" reserve has been shown to support a similar number of bee species to the proposed "Folusz" reserve.

The Kietrz region, along with the "Góra Gipsowa" reserve, is colonized by a relatively small number of species with southerly distribution ranges. Of course, this may be due to the low intensity of research there. Analysis of their distribution in Poland indicates that some of them (Hylaeus punctatus, Lasioglossum nigripes) have migrated to the study area from other directions, i.e. from the east and west. The attempt in this study to assess the role of the Moravian Gate as a migration route of southern species to Poland from the Danube catchment area suggests that it plays a relatively small role. This is consistent with the results of earlier research on orthopterans (LiANA 1976), heteropterans (HEBDA 2002) and beetles (KUŚKA 1977, 1981, 2001, 2006, 2007).

Another issue is the condition of the fauna of the reserve and its vicinity before intensive farming was started in this region and before livestock grazing was banned in the reserve. German researchers (KeILHOLZ 1927) reported large proportions of southern species, and some zoologists may have been inspired by the logical association of the areas on either side of the Carpathians and Sudetens. A different and interesting opinion was cited by KozŁowSKA (1936), who suggested that in comparison to the neighbouring Moravia, the fauna of the Cieszyn Foothills contained only species and whole communities associated with a more or less humid climate. In spite of the favourable substrate, we did not record in the study area any typical steppe species of Apiformes, genetically linked with south-eastern Europe and central Asia. The steppe communities in the southern part of the Moravian Gate remain separate. The line of contact between the Carpathians and the Sudetens between Cieszyn and Brno is the barrier that prevented the northward migration of steppe plants. As KUŚKA (2001) emphasized, there are no xerothermic habitats along the humid valley of the Oder from the river head in the Oderské Vrchy Mountains to the frontier with Poland. This contrasts with the striking richness in southern species on the 
south sides of the Carpathians and Sudetens (LUKÁŠ 1983, 1987, PřIDAL \& VESELÝ 2011). The "Trenčianska Skalka", the "Turecko" nature reserve and the "Mohelno Serpentine Steppe" national nature reserve all lie farther south than Lower Silesia. Some of the species mentioned here have thermal limits. Thermophilous species recorded in the "Mohelno Serpentine Steppe" probably have a considerable migration capability because this habitat lies at an elevation of $400 \mathrm{~m}$.

The results of this study appear to indicate that at present the Moravian Gate does not play any part in the migration of southern bee species to Poland. To confirm these remarks, however, further research is needed in the "Góra Gipsowa" reserve and other the habitats near Kietrz.

\section{REFERENCES}

BANASZAK J. 1980. Bees (Apoidea, Hymenoptera) of xerothermal habitats in the region of lower Vistula. Fragmenta Faunistica 25(19): 335-360. (in Polish)

BAnaszaK J. 2000. Contribution to bee fauna (Hymenoptera, Apoidea) of Poland. IV. Acta Universitatis Lodziensis, Folia Zoologica 4: 25-28.

Banaszak J. 2004. Apidae. [in:] W. Bogdanowicz, E. Chudzicka, I. Pilipiuk, E. Skibińska (eds.). Fauna of Poland. Characteristics and checklist of species, Volume 1. Muzeum i Instytut Zoologii Polskiej Akademii Nauk, Warszawa, 358-362. (in Polish)

BANASZAK J. 2010. Bees of the Masurian Landscape Park: diversity and ecology (Hymenoptera: Apoidea, Apiformes). Polish Journal of Entomology 79(1): 25-53.

BANASZAK J., CIERZNIAK T. 2002. Environmental islands in the agricultural landscape as refuges for pollinating insects - valorization attempt. [in:] J. BANASZAK (ed.). Habitat islands. Biodiversity and typology. Wydawnictwo Akademii Bydgoskiej im. Kazimierza Wielkiego, Bydgoszcz, 105-125. (in Polish)

BANASZAK J., CieRZniak T., RATyŃSKA H. 2003. Local changes in populations of wild bees (Hymenoptera: Apoidea): 20 years later. Polskie Pismo Entomologiczne 72(3): 261-282.

BANASZAK J., Michalik S., FiJAE J., Kosior A. 1998. Effect of succession of non-forest communities on Apoidea in the Skołczanka forest-steppe reserve. Prądnik. Prace Muzeum Szafera 11-12: 223-250. (in Polish)

BAnASZAK J. Motyka E., SzCZEPKo K. 2013a. Andrena florivaga Eversmann, 1852 (Hymenoptera: Apoidea: Andrenidae) - a new bee species of the genus Andrena in Poland. Journal of Apicultural Science 57(1): 45-50.

BANASZAK J., RATYŃSKA H., BANASZAK W.A. 2004. Proposed "Folusz" Nature Reserve near Szubin (in Poland) as a refuge of thermophilous plant cover and the fauna of the superfamilies Apoidea and Scolioidea. Badania Fizjograficzne nad Polską Zachodnią, seria C Zoologia 50: 101-132. (in Polish) 
BANASZAK J., RATYŃSKa H., SZEFER P. 2013b. Diversity of bees and associated plant cover. The case of "Ostrów Małe Rudy" habitat island in the Noteć River valley near Bydgoszcz (Hymenoptera, Apoidea, Apiformes). Badania fizjograficzne, seria C Zoologia 54: 29-56.

Banaszak J., Romasenko L., Cierzniak T. 2001. Keys to identification of Polish insects 24(68f). Apidae. Subfamily Megachilinae. Hymenoptera. Polskie Towarzystwo Entomologiczne, Torun. (in Polish)

BANASZAK J., Twerd L., Kriger R., Motyka E. 2010. Need for protection of xerothermic grasslands to preserve of bee fauna. [in:] H. RATYŃSKA, B. WALDON (eds.). Thermophilous grasslands in Poland - state of preservation and protection perspectives. Wydawnictwo Uniwersytetu Kazimierza Wielkiego, Bydgoszcz: 482-492. (in Polish)

BANASZAK J., Twerd L., Twerd J. 2013c. Results of the preliminary studies of bee fauna diversity in the steppe reserve "Gipsowa Gora" in Opole province. Chrońmy Przyrodę Ojczystą 69(5): 422-429. (in Polish)

Biodiversity Map [online]. Polish Biodiversity Information Network. Internet: http://gis.biomap.pl (Accessed 15 March 2016)

Bogusch P., StRaka J. 2012. Review and identification of the cuckoo bees of central Europe (Hymenoptera: Halictidae: Sphecodes). Zootaxa 3311: 1-41.

BuszKo J. 1990. Structure and dynamics of the distribution ranges of mining Lepidoptera in lower Vistula Valley. Uniwersytet Mikołaja Kopernika. Rozprawy, Toruń. (in Polish).

Celary W. 1988. Wild bees (Hymenoptera, Apoidea) of the Będkowska Valley (Kraków Częstochowa Upland). Part I. Colletidae, Halictidae. Acta Biologica Cracoviensia, Zoologia 30: $1-17$.

CELARY W. 1990. Review of the parasitic bees of the family Anthophoridae (Hymenoptera, Apoidea) in Poland (excluding the genus Nomada SCOP.). Polskie Pismo Entomologiczne 60(1): 9-23.

CELARY W. 1995. Nomadini (Hymenoptera, Apoidea, Anthophoridae) of Poland. Monografie Fauny Polski 20. Wydawnictwa Instytutu Systematyki i Ewolucji Zwierząt, Polskiej Akademii Nauk, Kraków.

Celary W. 1999. New and rare species of the genus Hylaeus Fabricius, 1793 for the fauna of Poland (Hymenoptera: Apoidea: Colletidae). Acta Zoologica Cracoviensia 42(2): 259-264.

Celary W. 2000. Wild bees (Hymenoptera: Apoidea) of Kraków-Częstochowa Upland. Part I. Colletidae and Halictidae. Acta Zoologica Cracoviensia 43(3-4): 261-279.

Celary W., Wiśniowski B. 2001. Contribution to bee fauna (Hymenoptera: Apoidea) of Poland. Acta Zoologica Cracoviensia 44(4): 413-418.

Celary W., WiŚniowski B. 2003. Contribution to bee fauna (Hymenoptera: Apoidea) of Poland. II. Acta Zoologica Cracoviensia 46(4): 359-364.

Celary W., WiŚniowsKi B. 2007. Contribution to the bee fauna (Hymenoptera: Apoidea: Anthophila) of Poland. III. Journal of Apicultural Science 51(1): 65-71.

Celary W., WiŚniowski B. 2011. Contribution to bee fauna (Hymenoptera: Apoidea: Anthophila) of Poland. IV. Journal of Apicultural Science 55(2): 141-148.

ChŁond D., Gorczyca J. 2009. Terrestrial true bugs (Hemiptera, Heteroptera) of the Ojców National Park - Origin of Fauna. Annales of the Upper Silesian Museum (Entomology) 17: 5-109. 
Cierzniak T., RATyŃSKa H., BANASZAK J., KaCZMAREK S. 2005. Influence of strict protection on xerothermic grassland and bee fauna on the esker near the Lake Budzyńskie (Wielkopolski National Park). Przegląd Przyrodniczy 16(3-4): 58-83. (in Polish)

CIEŚLAK E. 2015. Migration history of xerothermic plants on the area of the southern Poland, in terms of molecular data. Fragmenta Floristica et Geobotanica Polonica 22(1): 3-13. (in Polish).

DAtHe H.H. 1980. Die Arten der Gattung Hylaeus F. in Europa (Hymenoptera: Apoidea, Colletidae). Mitteilungen aus dem Zoologischen Museum in Berlin 56(2): 207-294.

DitTRICH R. 1903. Verzeichnis der bisher in Schlesien aufgefundenen Hymenopteren. I. Apidae. Zeitschrift für Entomologie 28: 19-54.

DubitZky A., Plant J., SchÖNITZER K. 2010. Phylogeny of the bee genus Andrena FABRicius based on morphology (Hymenoptera: Andrenidae). Mitteilungen der Münchner Entomologischen Gesellschaft 100: 137-202.

Dylewska M. 2000. Keys to the identification of Polish insects 24(68d). Apidae. Subfamily Andreninae. Hymenoptera. Polskie Towarzystwo Entomologiczne, Toruń. (in Polish)

DYlewska M., Noskiewicz J. 1963. Apoidea of the Pieniny National Park. Part II. Colletidae, Andrenidae, Halictidae, Melittidae, Apidae (Nomada ScOP.). Acta Zoologica Cracoviensia 8(13): $477-532$.

Greń C., SzoŁtys H., Grzywocz J., Królik R. 2015. Beetles (Coleoptera) of Lower and Upper Silesia - the current state of knowledge and new faunistic data: water scavenger beetles (Hydrophilidae). Acta Entomologica Silesiana 23: 1-24. (in Polish)

HaŁaj R., Osiadacz B. 2015. Aphis vitalbae FerRari, 1872 (Hemiptera: Aphididae): new finding on ornamental Clematis spp. in Poland. Phytoparasitica 43(1): 103-106.

HeBDA G. 2002. Terrestrial bugs Heteroptera (Insecta: Hemiptera) of the "Gipsowa Góra" Nature Reserve in Poland. Časopis Slezského zemského muzea. Série A, Vědy přírodní 51: 91-95.

HeBDA G. 2004. Nature Reserves "Ligota Dolna" and "Gipsowa Góra" as a refuge of xerothermophilous fauna of Heteroptera. Wiadomości Entomologiczne 23(2): 144-145. (in Polish)

KARG J. 1966. Water-bugs (Heteroptera) of Gliwice and Rybnik environs. Fragmenta Faunistica 12(17): 281-307. (in Polish)

KasprzaK K., Niedbala W. 1981. Biocenotic indices used in organizing and analysing data in quantitative studies. [in:] M. GóRnY, L. GRÜM (eds.). Methods in soil zoology. Wydawnictwo Naukowe PWN, Warszawa, 397-416. (in Polish)

KeIlHOlZ R. 1927. Die pontische Pflanzengemeinschaft der Gipsberge bei Katscher. Der Oberschlesier 1927(9) 326-336.

KONDRACKi J. 2002. Regional geography of Poland. Wydawnictwo Naukowe PWN, Warszawa. (in Polish)

KowALCZYK J.K. 1997. New localities of sting wasp species (Hymenoptera: Aculeata) in Poland. Wiadomości Entomologiczne 16(1): 53-54. (in Polish)

KowalCZyK J.K., KurZaC T., SoszyŃSKi B. 2009a. Amegilla quadrifasciata (VILlers, 1789) (Hymenoptera, Apoidea) - a new locality of a rare polilectic bee in Poland. Chrońmy Przyrodę Ojczystą 65(3): 231-233. (in Polish) 
Kowalczyk J.K., KurZaC T., SoszyŃSki B. 2009b. New localities of interesting Aculeata (Hymenoptera) in Łódź region. Parki Narodowe i Rezerwaty Przyrody 28(2): 127-134. (in Polish)

KozŁowsKa A. 1936. Charakterystyka zespołów leśnych Pogórza Cieszyńskiego. [in:] A. KozŁowsKa, R. WilczeK, I. ReJMENT, I.H. KsiĄżKównA, Z. STUGLiK. Biocenoza lasów Pogórza Cieszyńskiego. Wydawnictwo Śląskie Polska Akademia Umiejętności, Prace Biologiczne 1: $1-78$.

KRÓLIK R. 2010. Mantis religiosa religiosa (Linnaeus, 1758) (Mantodea) in Poland. Acta Entomologica Silesiana 18: 5-7. (in Polish)

Kuntze R., Noskiewicz J. 1938. Versuch einer Zoogeographie des polnischen Podoliens. Prace Naukowe. Wydawnictwo Towarzystwa Naukowego we Lwowie, Dział II, 4: 1-538. (in Polish)

KUŚKA A. 1977. Materials to the knowledge of weevils (Coleoptera, Curculionidae) of the outlet of the Moravian Gate in Poland. Polskie Pismo Entomologiczne 47(1): 3-16. (in Polish)

KuŚKA A. 1981. Comments on the protection of steppe reserves in Silesia. Chrońmy Przyrodę Ojczystą 37(3): 62-64. (in Polish)

KuŚKA A. 2001. The weevils (Coleoptera: Rhynchitidae, Apionidae, Nanophyidae, Curculionidae) of the xerothermic places of Upper Silesia. Natura Silesiae Superioris 5: 61-77. (in Polish)

KUŚKA A. 2006. Legal protection of selected xerothermic sites in Górny Śląsk and Jura KrakowskoCzęstochowska and its influence on the changes in coleopterofauna. Wiadomości Entomologiczne 25(2): 121-130. (in Polish)

KuŚKA A. 2007. The beetles fauna of Upper Silesia and its relations to the fauna of the Czech Republic and Moravia. [in:] J.A. LIs, A. MAZUR (eds.). Natural values of the Polish-Czech border as a common heritage of the European Union. Centrum Studiów nad Bioróżnorodnością, Uniwersytet Opolski, 29-35. (in Polish)

LiAnA A. 1976. Les Orthoptères dans les habitats xérothermiques sur le Plateau de Małopolska. Fragmenta Faunistica 20(25): 469-558. (in Polish)

Lis J.A., Lis B., ZiAJA D.J. 2012. Heteroptera Poloniae 2. Pentatomoidea. Part 1. Plataspidae, Thyreocoridae, Cydnidae, Acanthosomatidae, Scutelleridae. Centrum Studiów nad Bioróżnorodnością, Opole. (in Polish)

LuKÁš J. 1983. The bees (Hymenoptera, Apoidea) of xerothermic locality Turecko. Zborník Slovenského národného Múzea, Prírodné Vedy 29: 137-171. (in Slovak)

LUKÁŠ J. 1987. Trenčianska Skalka - a refugium of the thermophilic stinging Hymenoptera (Aculeata). Zborník Slovenského národného Múzea, Prírodné Vedy 33: 41-94. (in Slovak)

ŁozIŃSKI P. 1920. Błonkówki pszczołowate okolic Krakowa. Sprawozdanie Komisji Fizjograficznej 53-54: $125-137$.

Macko S., Noskiewicz J. 1954. A station of Sedum album L. on Góra Wapienna near Stolec in the vicinity of Ząbkowice (Lower Silesia). A characteristic of the flora and fauna. Ochrona Przyrody 22: 167-194. (in Polish)

Macko S., Noskiewicz J. 1959. Living nature. [in:] K. PopioŁeK (ed.). Upper Silesia. Instytut Zachodni im. Zygmunta Wojciechowskiego, Poznań, 50-79. (in Polish) 
MAIER A. 2015. The Central European Magdalenian: Regional diversity and Internal Variability. Vertebrate Paleobiology and Paleoanthropology. Springer, Dordrecht.

MAtuszKiewicz J.M. 2008. Geobotanical regionalization of Poland. Instytut Geografii i Przestrzennego Zagospodarowania Polska Akademia Nauk, Warszawa. Internet: http://www.igipz.pan.pl/Regiony-geobotaniczne-zgik.html (Accessed 15 Mar. 2016)

MazuR M., Kubisz D. 2000. Protection of insects of xerothermic habitats in Poland. Wiadomości Entomologiczne 18(2): 129-137. (in Polish)

MazUr M., PawŁowski J. 1993. The problem of protection of the weevil Apion velatum Gerst. (Coleoptera, Apionidae). [in:] A.W. BIDERMAN, B. WiŚNIOWSKI (eds.). Preservation and restitution of declining species in national parks and nature reserves. Prądnik. Prace Muzeum Szafera 9: 83-88.

Medwecka-KornaŚ A., Kornaś J. 1977. Associations of steppes and dry grasslands. [in:] W. SzAFer, K. ZARZYCKI (eds.). Szata roślinna Polski. Third edition, Volume 1. Państwowe Wydawnictwo Naukowe, Warszawa, 352-366. [in Polish]

Melke A., Grzywocz J. 2002. Rove beetles (Coleoptera: Staphylinidae) collected in the "Gipsowa Góra" xerothermic reserve in Upper Silesia. Rocznik naukowy Polskiego Towarzystwa Ochrony Przyrody „Salamandra” 6: 49-56.

Michener Ch.D. 2007. The Bees of the World. Second edition. John Hopkins University Press, Baltimore, London.

Mirek Z., PięKoś-Mirkowa H., ZająC A., ZająC M. 2002. Flowering plants and pteridophytes of Poland. A checklist. W. Szafer Institute of Botany, Polish Academy of Sciences, Kraków.

Motyka E., Bystrowski C. 2016. Andrena saxonica Stoeckhert, 1935 (Hymenoptera: Apoidea: Andrenidae) - new species of bees of the genus Andrena in Poland. [in:] L. BuchHolz, M. BunAlski, P. SiENKIEWICZ (eds.). 50. Zjazd Polskiego Towarzystwa Entomologicznego oraz VIII Ogólnopolska Konferencja Naukowa z cyklu „Ochrona owadów w Polsce” nt. „Entomofauna leśna - różnorodność, ochrona i kierunki badań”, Sękocin Stary, 16-18 września 2016 r. Polskie Towarzystwo Entomologiczne, Poznań, 38.

Motyka E., Wiśniowski B., Szczepko K. 2016. The Wild Bees Andrena gallica Schmiedeknecht, 1883 and Andrena assimilis RADOSZKOWSKI, 1876 (Apoidea: Andrenidae) in Poland. Journal of Apicultural Science 60(2): 111-118.

Noskiewicz J. 1924. Contribtuon to the fauna of Aculeata in the vicinity of Kraków. Rozprawy i Wiadomości z Muzeum im. Dzieduszyckich 9: 112-115.

Noskiewicz J. 1950. Faunistic characteristics of Silesia. [in:] R. KobendZA, J. KobendzinA, Z. KACZOROWSKA, J. NoskiEWICZ. Farming on northern and western lands. 12. Physiography of the western and northern lands. Państwowy Instytu Nauk Rolniczych, Warszawa. (in Polish)

NosKIEWICZ J. 1959. New species of hymenopterans (Hymenoptera) and dipterans (Diptera) for Poland, and new localities of rare recorded species. Polskie Pismo Entomologiczne 29(14): 201-214. (in Polish)

ORDINANCE of the Regional Director of Environmental Protection in Opole of 29 December 2016 relating to the "Góra Gipsowa" nature reserve. Dziennik Urzędowy Województwa Opolskiego, Opole, dnia 30 grudnia 2016, poz. 2914. Internet: http://bip.opole.rdos.gov.pl/files/obwieszczenia/ 69546/w\%20sprawie\%20rezerwatu\%20przyrody\%20G\%C3\%B3ra\%20Gipsowa.pdf (Accessed 10 May 2017) (in Polish) 
OsYTSHnJUK A.Z. 1977. Fauna of the Ukraine 12(5). Apoidea - Andrenidae. Zoological Institute, Academy of Sciences of Ukraine, Kiev. (in Ukrainian)

Pawlikowski T., Celary W. 2003. Keys to identification of Polish insects 24(68a). Apidae. Introduction and Subfamily Colletinae. Hymenoptera. Polskie Towarzystwo Entomologiczne, Torun. (in Polish)

Pawlikowski T., Olszewski P., ŻyŁa W., PrZybylińska M. 2016. The rare oligolectic bumblebee Bombus gerstaeckeri MoRAwITZ, 1882 from Poland (Hymenoptera, Apidae). Spixiana 39(1): 130.

PawŁowska S. 1977. Elements of the Polish flora. [in:] W. Szafer, K. Zarzycki (eds.). Szata roślinna Polski. Tom 1. Państwowe Wydawnictwo Naukowe, Warszawa: 131-206. (in Polish)

PENN J.R. 2001. Rivers of the World: A Social, Geographical, and Environmental Sourcebook. ABCCLIO, Santa Barbara, CA.

Pesenko Yu.A., Banaszak J., Radchenko V.G., Cierzniak T. 2000. Bees of the family Halictidae (excluding Sphecodes) of Poland: taxonomy, ecology, bionomics. Wydawnictwo Uczelniane Wyższej Szkoły Pedagogicznej w Bydgoszczy, Bydgoszcz.

Pesenko Yu.A., BAnaszaK J., CierzniaK T. 2002. Keys to identification of Polish insects 24(68b). Apidae. Subfamily Halictinae. Hymenoptera. Polskie Towarzystwo Entomologiczne, Torun. (in Polish)

PřIDAL A. 2014. New and interesting records of bees from Moravia and Slovakia with remarks to the Czech and Slovak checklist of bees (Hymenoptera: Apoidea: Apiformes). Klapalekiana 50: $73-83$.

PřIdAl A., VeselÝ P. 2011. Changes in the composition of the bee populations of the Mohelno Serpentine Steppe after 70 years (Hymenoptera: Apiformes). Acta Universitatis Agriculturae et Silviculturae Mendelianae Brunensis 59(6): 291-311.

PrZYBYŁowicz Ł. 2006. Bittacus hageni BrAUER, 1860 (Mecoptera: Bittacidae) - new to the fauna of Poland, with some remarks on Polish specimen of Bittacus italicus (O.F. MüLlER, 1766). Polskie Pismo Entomologiczne 75(3): 333-337.

RAfALSKI J. 1960. Catalogus faunae Poloniae 32(2). Harvestmen Opiliones. Panstowe Wydawnictwo Naukowe, Warszawa.

Regulation of the Minister of Environmental Protection of 16 December 2016 about conservation of animal species. Dziennik Ustaw 2016, poz. 2134. Internet: http://www.dziennikustaw.gov.pl/du/ 2016/2183/1 (Accessed 5 Feb. 2017) (in Polish)

SENDEK A., BABCZYŃSKA-SENDEK B. 1990. Problems of xerothermic vegetation protection in the reserves Góra Gipsowa and Ligota Dolna in the Opole region. Prądnik. Prace Muzeum Szafera 2: 17-21. (in Polish)

SOBIERAJ-BETLIŃSKA A. in press. Tritomegas sexmaculatus (RAMBUR, 1839) (Hemiptera: Heteroptera: Cydnidae) - the second locality in Eastern Sudetes. Wiadomości Entomologiczne. (in Polish)

Straka J., Bogusch P., Přidal A. 2007. Apoidea: Apiformes (včely). [in:] P. Bogusch, J. STRAKA, P. KMENT (eds.). Annotated checklist of the Aculeata (Hymenoptera) of the Czech Republic and Slovakia. Acta Entomologica Musei Nationalis Pragae 11: 241-299. (in English and Czech) 
Straka J., Bogusch P., Tyrner P., Říha M., Benda D., Č́̇̌̌ek O., Halada M., MacháčKová L., Marhoul P., TropeK R. 2015. Faunistic records from the Czech Republic - 380. Klapalekiana 51(1-2): 77-91.

SURDACKI S. 1965. Distribution and Variability of the European souslik, Citellus citellus (LinNAEus, 1766) in Poland. Acta Theriologica 10(19): 273-288. (in Polish)

SzAFER W. 1926. Meaning of the Moravian Gate as a way of migration of plants from the south to Poland. [in:] Sborník I. Sjezdu Slovanských Geografů a Etnografů v Praze 1924. Výdal Vybor Sjezdu. Geografický Ustav Karlovy University, Praha, 209.

SZAFRAŃSKI P. 2011. Eucharitidae (Hymenoptera), a chalcid wasp family new to the fauna of Poland. Polish Journal of Entomology 80(3): 547-554.

SzYMCZAKOWSKI W. 1965. Materials to the knowledge of beetles (Coleoptera) of xerothermic habitats in Poland. Polskie Pismo Entomologiczne 35(5): 225-257. (in Polish)

Twerd L., BAnaszaK J. 2013. Conservation problems of bee fauna (Hymenoptera: Apoidea, Apiformes) in reserve "Góra Gipsowa". Inżynieria Ekologiczna 33: 147-155. (in Polish)

WANAT M., CELADYN R. 2015. A second locality of Helianthemapion velatum (GERSTAECKER, 1854) (Coleoptera: Apionidae) in Poland. Wiadomości Entomologiczne 34(2): 53-58. (in Polish)

Wendzonka J. 2014. Hylaeus (Paraprosopis) lineolatus (SCHENCK, 1861) (Hymenoptera, Apoidea, Colletidae) - a new species in Polish fauna. Wiadomości Entomologiczne 33(2): 139-145. (in Polish)

WiŚNiowski B., Piotrowski W. 2013. Contribution to the knowledge of wasps and bees (Hymenoptera, Aculeata) of Poleski National Park in Poland. Parki Narodowe i Rezerwaty Przyrody 32(2): 15-29. (in Polish)

WODZICZKo A., URBAŃSKi J., CZUBIŃSKi Z. 1948. Living nature of the valley of the River Odra and its protection. [in:] A. GrodkA, M. KietcZewsKa-Zaleska, A. Zierhoffera (eds.). Monografia Odry. Studium zbiorowe. Instytut Zachodni, Poznań, 302-350. (in Polish)

Woś A. 1993. Climatic regions of Poland in the light of the frequency of various weather types. Zeszyty Instytutu Geografii i Przestrzennego Zagospodarowania PAN 20: 1-91. (in Polish)

Received: 3 March 2017

Accepted: 18 May 2017 